\title{
PENGGUNAAN STRATEGI TIPE ACTIVE KNOWLEDGE SHARING DALAM PEMBELAJARAN SOSIOLOGI DI SEKOLAH MENENGAH ATAS
}

\author{
Zainun \\ SMA Negeri 7 Sarolangun \\ Email : abiyanzahdan2014@yahoo.com
}

\begin{abstract}
Abstrak
Penelitian ini dilatar belakangi oleh rendahnya nilai Sosiologi siswa di SMA Negeri 7 Sarolanun. Penelitian ini bertujuan untuk mengetahui bagaimana penggunaan strategi pembelajaran aktif tipe Active Knowledge Sharing agar dapat meningkatkan hasil belajar Sosiologi. Penelitian ini merupakan penelitian tindakan kelas yang dilaksanakan dalam tiga siklus. Penelitian di ambil secara kualitatif dan kuantitatif. Pengambilan data kualitatif dengan lembar penilaian. Sedangkan data kuantitatif untuk mengetahui peningkatan hasil belajar siswa. Hasil penelitian, peningkatan hasil belajar siswa dinilai dari aspek pengetahuan setiap siklus yaitu, 62,95 siklus I menjadi 67,86,untuk siklus II dan 75,00 untuk siklus III, untuk hasil belajar siswa yang dinilai dari aspek sikap setiap siklus yaitu 46,43\% untuk siklus I menjadi 64,29\% untuk siklus II dan 76,58\% untuk siklus III dan penilaian dari aspek keterampilan setiap siklus yaitu, 32,14 \% untuk siklus I 53,57\% untuk siklus II dan 82,15\% untuk siklus III. Dengan demikian dapat disimpulkan bahwa penerapan strategi pembelajaran aktif tipe Active Knowledge Sharing dapat meningkatkan hasil belajar siswa pada materi Integrasi dan Reintegrasi.
\end{abstract}

Kata Kunci: Active Knowledge Sharing, Hasil Belajar, Strategi Pembelajaran,

\section{THE USE OF INSTRUCTIONAL STRATEGIES TYPE ACTVIE KNOWLEDGE SHARING ON SOCIOLOGY IN HIGHER SCHOOL}

\author{
Zainun \\ SMA Negeri 7 Sarolangun \\ Email: abiyanzahdan2014@yahoo.com
}

\begin{abstract}
Backgrounds of the research is the low of SMA Negeri 7 Sarolangun student value ini socialogy subject. The aim of the research is to know whetter the "active knowledge sharing" can improve te sociology learning outcame. This is a classroom research which has 3 cyeles. It is a qualitiatif and qwantitatif research. Qualitatif data collected by using adsessment sheet while qualitatif data to measure the progress of student learnin oucome. The resesult of the research is the increasing of student learning outcome assess from the knowledge aspect in each cycle whic are: $1^{\text {st }}$ cycle from 62,95 rise to 67,86 in $2^{\text {nd }}$ cycle and $3^{\text {rd }}$ cycle 75 in attitude aspect from $45,43 \%$ in $1^{\text {st }}$ cycle, to $64,29 \%$ in $2^{\text {nd }}$ cycle and $76,58 \%$ in $3^{\text {rd }}$ cycle and skill aspect, 32, 14\%, for the 1 st scyle $53,57 \% 2^{\text {nd }}$ cycle and $82,15 \%$ for the $3^{\text {rd }}$ cycle it can be conclude that the application of "active knowledge sharing" learning strategy can in crease student learnin outcome in integration and reintegration
\end{abstract}

Keywords: learning, outcome, learnin strategy, active knowledge sharing 


\section{PENDAHULUAN}

Proses belajar mengajar dapat terlaksana dengan baik apabila terdapat interaksi yang baik antara guru dan siswa (Sardiman. 2012). Agar tercipta interaksi tersebut maka dibutuhkan pembelajaran yang dapat melibatkan aktivitas siswa (Koesoema. 2007). Dari hasil observasi yang dilakukan dengan guru bidang studi Sosiologi di SMA Negeri 7 Sarolangun, diperoleh informasi bahwa ada permasalahan dalam proses pembelajaran, yaitu dalam aktivitas belajar masih banyak siswa yang tidak memperhatikan pelajaran dan kurangnya semangat dalam mengerjakan soal-soal yang diberikan oleh guru, siswa lebih banyak duduk diam di bangku masing-masing dan tidak mau bertanya kepada siswa lainnya yang telah memahami soal tersebut mata pelajaran Sosiologi tahun 2017/2018 seperti pada tabel berkut:

Tabel 1. Rata-Rata Ulangan Harian Semester 1 (Ganjil)

\begin{tabular}{lc}
\hline KELAS & Nilai Rata-rata (skala 10) \\
\hline XI IIS 1 & 6,40 \\
XI IIS 2 & 6,40 \\
XI IIS 3 & 7,25 \\
XI IIS 4 & 6,50 \\
XI IIS 5 & 7,20 \\
\hline (Sumber: Guru Sosiologi SMA Negeri 7 \\
Sarolangun) \\
Berdasarkan tabel di atas dapat
\end{tabular}
dilihat bahwa rata-rata nilai ulangan harian siswa masih dibawah KKM yaitu 75 untuk kelas XI. Dari tabel tersebut terlihat bahwa kelas XI IIS 1 merupakan kelas yang ratarata nilai ulangan hariannya paling rendah yaitu 6,40. Faktor-faktor yang menyebabkan rendahnya nilai ulangan harian kelas XI IIS 1 tersebut antara lain disebabkan oleh situasi belajar siswa masih pasif dalam pembelajaran dibandingkan dengan kelas lain, hanya sedikit siswa yang berperan aktif dalam kegiatan pembelajaran, yang lainnya tidak peduli dengan kegiatan belajar mengajar yang berlansung dan berakibat munculnya komunikasi tidak baik antara guru dan siswa.

Agar mata pelajaran Sosiologi menjadi lebih menarik, aktivitas siswa menjadi meningkat dan hasil belajarnya tinggi maka perlu adanya perubahan dalam proses belajar mengajar, baik dalam cara mengajar maupun strategi yang digunakan. Upaya untuk meningkatkan kompetensi siswa, guru sebaiknya mampu menciptakan kondisi pembelajaran yang efektif. Agar dapat mengajar efektif, guru harus meningkatkan kesempatan belajar dan meningkatkan mutu mengajarnya (Yamin, 2007; 23). Berkenaan dengan masalah yang dikemukakan di atas salah satu strategi yang diharapkan cukup efektif untuk meningkatkan aktivitas siswa dalam belajar yakni dengan menerapkan strategi pembelajaran aktif tipe Active Knowledge Sharing dalam pembelajaran sosiologi.

\section{METODE}

Jenis penelitian ini adalah kuantitatif yaitu mengunakan data yang berbentuk angka. (Sugiono, 2011; 117) Penelitian ini 
dilaksanakan dalam tiga siklus yaitu terdiri dari siklus I, siklus II, dan siklus III. Dalam penelitian ini peneliti bekerjasama dengan guru bidang studi Sosiologi yang mengajar di kelas tersebut. Dalam hal ini peneliti ikut dalam setiap kegiatan belajar yang berlangsung untuk mengamati proses pembelajaran. Pada setiap siklus memiliki tahapan-tahapan tertentu sesuai dengan tahapan dalam tindakan kelas yang dikemukakan oleh Arikunto (2012), yaitu (1) perencanaan, (2) pelaksanaan, (3) pengamatan, dan (4) refleksi.

\section{HASIL DAN PEMBAHASAN}

Penelitian tindakan kelas ini dilaksanakan dalam tiga siklus. Siklus I merupakan pelaksanaan tindakan awal yang dilakukan pada pelaksanaan penelitian tindakan kelas ini. Pada siklus I, pelaksanaan tindakan dilakukan dua kali pertemuan dan satu kali ujian siklus. Pertemuan pertama mengenai materi konsep usaha pada integrasi dan reintegrasi, faktor pendorong terjadinya integrasi dan reintegrasi. Pelaksanaan pembelajarannya lebih menitikberatkan pada hasil belajar siswa pada aspek sikap, keterampilan dan pengetahuan dengan menggunakan strategi pembelajaran Aktif Tipe Active Knowledge Sharing tujuan untuk meningkatkan hasil belajar siswa. Setelah melakukan 2 kali pertemuan, pada pertemuan terakhir untuk siklus I, siswa diberikan tes dalam bentuk ulangan formatif untuk mengetahui penguasaan siswa terhadap materi pembelajaran yang telah diajarkan. Tes yang diberikan ini terdiri dari 10 soal pilihan ganda yang terkait dengan materi Integrasi dan reintegrasi Soal-soal tes ini sebelumnya telah dianalisis melalui uji validitas, reliabilitas, daya beda serta tingkat kesukarannya. Hasil observasi menunjukkan bahwa ada beberapa aktivitas yang dapat dikategorikan kurang dan perlu ditingkatkan antara lain 1) kurangnya perhatian siswa saat memulai pelajaran sehingga banyak waktu yang terbuang, 2) Banyak siswa yang kurang perhatian saat guru menjelaskan tujuan pembelajaran, 3) hanya sebagian siswa yang menaggapi apersepsi dari guru, 4) hanya sebagian siswa yang termotivasi untuk belajar, 5) kurang tegasnya guru dalam memberikan instruksi sehingga banyak siswa yang tidak memperhatikan saat guru memberikan instruksi, 6) kurangnya kerjasama dalam kelompok, hanya sebagain yang aktif dalam kelompok, 7) rendahnya rasa ingin tahu pada siswa sehingga sedikitnya jumlah siswa yang bertanya, 8) kurang beraninya siswa dalam mengungkapkan pendapatnya atau dengan kata lain siswa takut salah saat berpendapat, 9) kurang interaktifnya suasana saat proses pembelajaran berlangsung, 10) kurang aktifnya siswa dalam menyimpulkan materi pembelajaran, 11) apresiasi yang kurang tegas sehingga kurangnya perhatian siswa

Hasil observasi pada instrument penilaian sikap yang dilakukan merupakan 
gambaran terhadap sikap siswa selama proses belajar mengajar berlangsung. Secara keseluruhan sikap siswa pada siklus I dapat dilihat pada tabel 2 berikut ini.

Tabel 2 Pengamatan Sikap Pada Diskusi Kelompok Siklus I

\begin{tabular}{clcc}
\hline No & $\begin{array}{l}\text { Variabel yang } \\
\text { diamati }\end{array}$ & Jumlah & $\begin{array}{c}\text { Persentase } \\
(\%)\end{array}$ \\
\hline 1 & $\begin{array}{l}\text { Jumlah siswa } \\
\text { yang Sangat }\end{array}$ & & \\
& $\begin{array}{l}\text { Baik (SB) } \\
\text { Jumlah siswa }\end{array}$ & 13 & $46,43 \%$ \\
& & \\
yang Baik (B) & & \\
& $\begin{array}{l}\text { Jumlah siswa } \\
\text { yang Cukup (C) }\end{array}$ & 15 & $53,57 \%$ \\
3 & $\begin{array}{l}\text { Jumlah siswa } \\
\text { yang Kurang } \\
\text { (K) }\end{array}$ & & \\
\hline
\end{tabular}

Tabel 2 dari 28 siswa, jumlah siswa yang termasuk sikap kategori baik dalam proses kegiatan belajar mengajar yaitu 13 siswa atau 46,47 \% dari jumlah siswa keseluruhan, sedangkan 15 siswa atau 53,57 $\%$ termasuk sikap kategori cukup. Hal ini mengindikasikan bahwa sikap siswa dalam kegiatan pembelajaran belum mencapai kriteria yang diharapkan. Untuk itu perlu diadakan tindakan lanjutan agar indikator keberhasilan tersebut dapat tercapai.

Hasil observasi pada instrument penilaian keterampilan yang dilakukan merupakan gambaran terhadap keterampilan siswa selama proses belajar mengajar berlangsung. Secara keseluruhan keterampilan siswa pada siklus I dapat dilihat pada tabel 3. Penilaian aspek keterampilan pada siklus I ini dinilai dari persentasi kelompok. Berdasarkan tabel 3 dari 28 siswa ,jumlah siswa yang memiliki nilai keterampilan berpredikat B- yaitu 9 siswa atau 32,14 \%, sedangkan jumlah siswa dengan kategori $\mathrm{C}+$ dalam proses belajar mengajar yaitu 10 siswa atau $35,71 \%$, dan 9 siswa atau $32,14 \%$ yang memiliki nilai keterampilan berpredikat $\mathrm{C}$, Hal ini mengindikasikan bahwa keterampilan siswa dalam kegiatan pembelajaran belum mencapai kriteria yang diharapkan. Untuk itu perlu diadakan tindakan lanjutan pada siklus II.

Tabel 3. Pengamatan Keterampilan

\section{Pada Persentasi Kelompok Siklus I}

\begin{tabular}{clcc}
\hline No & $\begin{array}{c}\text { Variabel yang } \\
\text { diamati }\end{array}$ & $\begin{array}{c}\text { Jumlah } \\
\text { Siswa }\end{array}$ & $\begin{array}{c}\text { Presentase } \\
(\%)\end{array}$ \\
\hline 1 & kategori A & - & - \\
2 & kategori A- & - & - \\
3 & kategori B+ & - & - \\
4 & kategori B & - & - \\
5 & kategori B- & 9 & $32,14 \%$ \\
6 & kategori C+ & 10 & $35,71 \%$ \\
7 & kategori C & 9 & $32,14 \%$ \\
8 & kategori C- & - & - \\
9 & kategori D+ & - & - \\
10 & kategori D & - & - \\
\hline
\end{tabular}

Hasil belajar yang diperoleh siswa dari tes formatif dapat dilihat pada tabel 4 .

Tabel 4. Hasil Belajar Pada Aspek Pengetahuan Siklus I

\begin{tabular}{llcc}
\hline No & $\begin{array}{c}\text { Variabel yang } \\
\text { diamati }\end{array}$ & Jumlah & $\begin{array}{c}\text { Persentase } \\
(\%)\end{array}$ \\
\hline 1 & $\begin{array}{l}\text { Nilai rata-rata } \\
\text { siswa }\end{array}$ & 62,95 & - \\
2 & $\begin{array}{l}\text { Jumlah siswa } \\
\text { yang mencapai }\end{array}$ & 12 & $44,44 \%$ \\
& $\begin{array}{l}\text { KKM } \\
\text { Jumlah siswa } \\
\text { yang belum } \\
\text { mencapai KKM }\end{array}$ & 15 & $53,57 \%$ \\
\hline
\end{tabular}

Tabel 4 dari 27 orang siswa yang mengikuti tes hasil belajar, jumlah siswa yang berhasil 12 orang atau $44,44 \%$ dari jumlah siswa keseluruhan yang nilainya berada di atas Kriteria Ketuntasan Minimun $(\mathrm{KKM})$, yaitu $\geq 75$. Nilai rata-rata siswa 
masih rendah yaitu 62,95, hal ini menunjukkan bahwa pelaksanaan proses pembelajaran pada siklus I ini masih benyak terdapat kekurangan dan perlu ditingkatkan pada siklus selanjutnya, yaitu dengan melaksanakan pelaksanaan tindakan pada siklus II.

Kegiatan setelah observasi yaitu refleksi. Ketidak berhasilan dapat dilihat dari rendahnya hasil belajar siswa. Hal tersebut disebabkan oleh adanya kendala dari aspek sikap dan keterampilan siswa yang masih kurang dalam peroses belajar mengajar. Adapun kendala yang dihadapi pada pelaksanaan proses belajar mengajar pada siklus I pada aspek afektif (Sikap) : a) interaksi siswa dalam kontek pembelajaran kelompok masih kurang, b) siswa belum bersungguh-sugguh dalam mengerjakan tugas kelompok, c) siswa belum dapat bekerja sama dalam belajar kelompok, d) siswa masih kurang berani berpendapat, bertanya atau menjawab pertanyaan teman kelompok lain. Pada aspek psikomotor (Keterampilan) antara lain a) siswa kurang menguasai topik permasalahan, argumentasi kurang banyak, dan arah pembicaraan kurang jelas, b) metode penyajiannya masih kurang, siswa masih berbicara kurang lancar, kadang berhenti dan tersendat, c) teknik bertanya jawab masih kurang, d) siswa masih takut menyampaikan pendapat (persetujuan atau sanggahan).

Untuk memperbaiki kekurangan kekurangan yang ada pada siklus I dan meningkatkan hasil belajar siswa pada siklus II, dilakukan perbaikan-perbaikan pada halhal berikut antara lain a) guru harus memperhatikan kondisi saat melaksanakan pembelajaran, baik waktu, tempat maupun kesiapan siswa, b) guru harus bisa mengendalikan kondisi kelas sebelum memulai proses pembelajaran, c) guru tetap mempertahankan hal-hal yang baik pada siklus I, d) guru memberikan motivasi kepada siswa untuk lebih berani menyampaikan pendapat, e) guru lebih aktif dalam membimbing siswa membentuk kelompok, f) guru lebih aktif dalam membimbing siswa untuk saling bekerja sama dan menegur siswa yang pasif dalam kelompok, g) guru memfasilitasi kerja siswa dan membantu siswa yang mengalami kesulitan, h) guru menegakkan disiplin waktu kepada siswa dalam mengerjakan tugas kelompok sesuai dengan waktu yang ditentukan, i) guru membagi kelompok siswa lebih banyak sehingga dalam kelompok terdapat jumlah siswa yang sedikit agar siswa dalam kelompok dapat aktif mengikuti proses berjalannya diskusi, j) guru mengegur siswa yang tidak memperhatikan guru menjelaskan materi pada saat evaluasi hasil diskusi, k) guru menanyakan ulasan-ulasan yang dijelaskan kepada siswa yang tidak memperhatikan guru sewaktu menjelaskan ulasan-ulasan, dengan harapan agar siswa mau memperhatikan. 
Tindakan yang dilaksanakan pada siklus II dibagi dalam dua kali pertemuan, pertemuan pertama mengenai hubungan ingrasi sosial dan reintegrasi. Pertemuan kedua membahas mengenai hubungan integrasi fakto penyebab integrasi dan reintegrasi . Untuk mengetahui penguasaan siswa pada materi yang telah diajarkan pada siklus II, maka diadakan ulangan formatif II dengan jumlah soal 10 butir dalam soal pilihan ganda yang berkaitan dengan materi yang telah dipelajari sebelumnya. Hasil observasi proses pembelajaran siklus 2 disimpulkan bahwa terjadi peningkatan pada proses pembelajaran, ada 10 aktivitas guru yang tercapai dengan baik dan sangat baik. Adapun beberapa aktivitas yang dapat dikategorikan kurang dan perlu ditingkatkan lagi antara lain a) masih banyak siswa yang tidak memperhatikan saat guru memberikan apersepsi, b) masih kurang tegasnya guru dalam memberikan instruksi sehingga masih ada beberapa siswa sibuk dengan kegiatan lain saat guru memberikan instruksi, c) kurang beraninya siswa dalam mengungkapkan pendapatnya atau dengan kata lain siswa takut salah saat berpendapat, d) suasana kelas masih kurang interaktif, e) masih ada beberapa siswa yang tidak memperhatikan saat menyimpulkan materi pembelajaran.

Penilaian sikap siklus 2 masih terdapat beberapa siswa yang belum memenuhi sikap yang dikatagorikan baik atau sangat baik. Secara keseluruhan sikap siswa pada siklus I tabel 5 berikut ini.

Tabel 5. Pengamatan Sikap Pada Diskusi Kelompok Siklus II

\begin{tabular}{llcc}
\hline No & $\begin{array}{c}\text { Variabel yang } \\
\text { diamati }\end{array}$ & $\begin{array}{c}\text { Jumlah } \\
\text { Sisiwa }\end{array}$ & $\begin{array}{c}\text { Persentase } \\
(\%)\end{array}$ \\
\hline 1 & Sangat Baik (SB) & - & - \\
2 & Baik (B) & 18 & $64,29 \%$ \\
3 & Cukup (C) & 10 & $35,71 \%$ \\
4 & Kurang (K) & & - \\
\hline
\end{tabular}

Terlihat pada tabel 5 dari 28 siswa, jumlah siswa yang termasuk sikap kategori baik dalam proses kegiatan belajar mengajar yaitu 18 siswa atau 64,29\% dari jumlah siswa keseluruhan, sedangkan 10 siswa atau $35,71 \%$ lainnya termasuk sikap kategori cukup.

Aspek keterampilan yang dinilai mengikuti beberapa aspek yang harus dimiliki siswa dalam berdiskusi kelompok. Secara keseluruhan keterampilan siswa pada siklus II dapat dilihat pada tabel 6 berikut.

\section{Tabel 6 Pengamatan Keterampilan Pada} Persentasi Kelompok Siklus II

\begin{tabular}{clcc}
\hline No & $\begin{array}{c}\text { Variabel } \\
\text { yang diamati }\end{array}$ & Jumlah & Presentase (\%) \\
\hline 1 & kategori A & - & - \\
2 & kategori A- & - & - \\
3 & kategori B+ & - & - \\
4 & kategori B & - & - \\
5 & kategori B- & 15 & $53,57 \%$ \\
6 & kategori C+ & 8 & $28,57 \%$ \\
7 & kategori C & 5 & $17,86 \%$ \\
8 & kategori C- & - & - \\
9 & kategori D+ & - & - \\
10 & kategori D & - & \\
\hline
\end{tabular}

Berdasarkan tabel 6 di atas, terlihat pada bahwa dari 28 siswa, jumlah siswa dengan kategori B- dalam proses kegiatan belajar mengajar yaitu 15 siswa atau 53,57 $\%$ dari jumlah siswa keseluruhan, sedangkan jumlah siswa dengan kategori $\mathrm{C}+$ dalam 
proses belajar mengajar yaitu 8 siswa atau $28,57 \%$ dan jumlah siswa dengan kategori C yakni 5 siswa atau $17,86 \%$. Hal ini mengindikasikan bahwa keterampilan siswa dalam kegiatan pembelajaran belum mencapai kriteria yang diharapkan.

Aspek pengetahuan, Hasil yang diperoleh siswa dari tes formatif pada siklus II menunjukkan tingkat pemahaman konsep yang dicapai siswa pada pokok bahasan siklus II.

Tabel 7. Hasil Belajar Pada Aspek Pengetahuan Siklus II

\begin{tabular}{llcc}
\hline No & $\begin{array}{l}\text { Variabel yang } \\
\text { diamati }\end{array}$ & Jumlah & $\begin{array}{c}\text { Persentase } \\
(\%)\end{array}$ \\
\hline 1 & $\begin{array}{l}\text { Nilai rata-rata } \\
\text { siswa }\end{array}$ & 67,86 & - \\
2 & $\begin{array}{l}\text { Jumlah siswa } \\
1\end{array}$ & 18 & $64,29 \%$ \\
& $\begin{array}{l}\text { yang mencapai } \\
\text { KKM }\end{array}$ & & \\
3 & $\begin{array}{l}\text { Jumlah siswa } \\
\text { yang belum } \\
\text { mencapai KKM }\end{array}$ & 10 & $35,71 \%$ \\
& & \\
\hline
\end{tabular}

Berdasarkan tabel 7 di atas, hasil belajar pada siklus II sudah mengalami peningkatan. Hal ini dapat diketahui dari nilai rata-rata yang di peroleh meningkat 65,00 pada siklus I menjadi 67,86 pada siklus II, dengan 18 siswa atau 64,29\% memperoleh nilai $\geq 75$. Sedangkan siswa yang belum mencapai KKM yakni 10 siswa yaitu 35,71 \%. Karena tindakan yang diberikan pada siklus II belum mencapai persentase indikator kerja yang ditetapkan, yaitu $75 \%$ dari jumlah keseluruhan siswa maka tindakan dilanjutkan pada siklus III.

Berdasarkan hasil siklus II maka dilakukan refleksi. Tingkat pemahaman konsep yang diperoleh melalui ulangan formatif II yang dikerjakan siswa, instrument penilaian keterampilan, dan instrument penilaian sikap, pelaksanaan siklus II sudah mengalami peningkatan dari siklus I. Hal ini terlihat dari peningkatan pemahaman konsep serta keaktifan siswa dalam proses belajar mengajar sudah meningkat, tetapi pemberian tindakan masih perlu dilanjutkan dan diharapkan pada siklus III terjadi peningkatan baik dalam hasil belajar dalam sikap, keterampilan dan pengetahuan.

Kendala-kendala yang dihadapi pada pelaksanaan proses belajar mengajar pada siklus II pada sspek Afektif (Sikap) antara lain a) siswa masih belum dapat bekerja sama dalam belajar kelompok, b) Siswa masih kurang menghargai pendapat teman dalam satu kelompok, c) aspek Psikomotor (Keterampilan), c) siswa masih kurang dalam membagi mengerjakan soal kelompok. Adapun kegiatan yang harus ditingkatkan dan dipertahankan antara lain a) kegiatan yang harus ditingkatkan berdasarkan instrument penilaian sikap pada siklus II adalah indikator 3,4 dan 5. Sedangkan yang dapat dipertahankan adalah indikator 1 dan 2, b) kegiatan yang harus ditingkatkan berdasarkan instrument penilaian keterampilan pada siklus II adalah indikator 3. 4 dan 5. Sedangkan yang dapat dipertahankan adalah indikator 1 dan 2 .

Setelah siklus II maka dilanjutnkan pada siklus III. Pelaksanaan tindakan yang dilakukan pada siklus III sama halnya 
dengan pelaksanaan tindakan pada siklus I dan II, yaitu terdiri dari dua kali pertemuan. Pelaksanaan tindakan sesuai dengan rencana pelaksanaan pembelajaran pertemuan $\mathrm{V}$ dan rencana pelaksanaan pembelajaran pertemuan VI. Pertemuan pertama mengenai integrasi dan reintegrasi, pertemuan kedua faktor pendorong intergrasi dan reintegrasi dalam kehidupan sehari-hari. Hasil observasi siklus III pada instrument penilaian sikap yang dilakukan merupakan gambaran terhadap sikap siswa selama proses diskusi kelompok berlangsung. Dalam kegiatan pembelajaran berlangsung masih terdapat beberapa siswa yang belum memenuhi sikap yang dikatagorikan baik atau sangat baik. Secara keseluruhan sikap siswa pada siklus III dapat dilihat pada tabel 8 .

\section{Tabel 8. Pengamatan Sikap Pada Diskusi} Kelompok Siklus III

\begin{tabular}{llcc}
\hline No & Nilai Sikap & Jumlah Siswa & $\%$ \\
\hline 1. & Sangat Baik (SB) & 5 & 17,86 \\
2 & Baik (B) & 18 & 64,29 \\
3 & Cukup (C) & 5 & 17,86 \\
4. & Kurang (K) & - & 0 \\
\hline
\end{tabular}

Berdasarkan Tabel 8 di atas, hasil belajar pada aspek sikap diperoleh 82,15\% siswa yang memiliki kriteria baik dengan jumlah 23 dari 28 siswa. Hal ini mengindikasikan bahwa sikap siswa dalam kegiatan pembelajaran semakin meningkat.

Hasil observasi pada instrument penilaian keterampilan yang dilakukan merupakan gambaran terhadap keterampilan siswa selama proses belajar mengajar berlangsung. Secara keseluruhan keterampilan siswa pada siklus III dapat dilihat pada tabel 9.

Tabel 9 Pengamatan Keterampilan Pada Persentasi Kelompok Siklus III

\begin{tabular}{|c|c|c|c|}
\hline $\begin{array}{l}\mathrm{N} \\
\mathrm{O}\end{array}$ & $\begin{array}{c}\text { Nilai } \\
\text { Keterampilan } \\
\text { (Predikat) }\end{array}$ & $\begin{array}{l}\text { Jumlah } \\
\text { Siswa }\end{array}$ & $\%$ \\
\hline 1. & kategori $\mathrm{A}$ & - & 0 \\
\hline 2. & kategori A- & - & 0 \\
\hline 3. & kategori B+ & - & 0 \\
\hline 4. & kategori B & 4 & 14,29 \\
\hline 5. & kategori B- & 19 & 67,86 \\
\hline 6. & kategori C+ & 5 & 17.86 \\
\hline 7 & kategori C & & \\
\hline 8 & kategori C- & & \\
\hline 9 & kategori D+ & & \\
\hline 10 & kategori D & & \\
\hline
\end{tabular}

Berdasarkan tabel di atas, hasil belajar pada aspek keterampilan diperoleh $82,15 \%$ siswa yang memiliki nilai di atas standar ketuntasan dengan jumlah 23 dari 28 siswa. Penilaian aspek pengetahuan, hasil yang diperoleh siswa dari tes formatif pada siklus III dapat dilihat pada tabel 10.

Tabel 10. Belajar Pada Aspek Pengetahuan Siklus III

\begin{tabular}{llc}
\hline No & \multicolumn{1}{c}{$\begin{array}{c}\text { Variabel yang } \\
\text { diamati }\end{array}$} & $\begin{array}{c}\text { Jumlah/ } \\
\text { persentase }\end{array}$ \\
\hline 1. & $\begin{array}{l}\text { Nilai rata-rata siswa } \\
\text { 2. }\end{array}$ & $\begin{array}{l}\text { Jumlah siswa yang } \\
\text { berhasil }\end{array}$ \\
3. & $\begin{array}{l}\text { Jumlah siswa yang } \\
\text { belum berhasil }\end{array}$ & $6(21,42 \%)$ \\
\hline & Berdasarkan tabel & $10, \quad$ dapat
\end{tabular}

diketahui bahwa pelaksanaan tindakan pada siklus III sudah mengalami peningkatan. Ini dapat diketahui dari hasil belajar siswa pada siklus III yang diikuti oleh 28 siswa, nilai rata-rata yang diperoleh meningkat dari 62,95 pada siklus I menjadi 64,29 pada siklus II dan meningkat lagi menjadi 75,00 pada siklus III. Siswa yang memperoleh 
nilai $\geq 75$ sebanyak 22 orang. Ini berarti keberhasilan siswa dalam pembelajaran mencapai 78,57\%.

Kegiatan selanjutnya yaitu refleksi siklus III. Aspek kognitif, seorang siswa dikatakan berhasil apabila telah mencapai nilai niminal 75 dan suatu kelas dikatakan mencapai keberhasilan bila di kelas tersebut terdapat $75 \%$ siswa telah mencapai nilai minimal. Untuk aspek sikap, pencapaian minimal nilai sikap siswa adalah B dan suatu kelas dapat dikatakan mencapai keberhasilan bila di kelas tersebut terdapat $\geq 60 \%$ siswa yang telah mencapai nilai maksimal. Sedangkan pada aspek keterampilan, ketuntasan minimal untuk seluruh kompetensi dasar yaitu $\geq 2,66$ (B-).

Perbandingan hasil siklus I, II, dan III mengenai peningkatan pemahaman siswa pada aspek kognitif yang diperoleh dari penerapan strategi pembelajaran Active Knowledge Sharing.

Tabel 11 Peningkatan Hasil Belajar Pada Aspek Pengetahuan Siswa Tiap Siklus

\begin{tabular}{llccc}
\hline \multirow{2}{*}{ No } & \multirow{2}{*}{ Variabel yang diamati } & \multicolumn{3}{c}{ Jumlah atau Persentase (\%) } \\
\cline { 2 - 4 } & & Siklus I & Siklus II & Siklus III \\
\hline 1 & Nilai rata-rata siswa & 62,69 & 67,86 & 75,00 \\
2 & Jumlah siswa yang mencapai KKM & $12(44,44 \%)$ & $18(64,29 \%)$ & $22(78,57 \%)$ \\
\hline
\end{tabular}

Berdasarkan tabel 11 dapat dilihat bahwa setiap siklus terdapat peningkatan pemahaman konsep yang semakin baik. Sehingga, dapat disimpulkan bahwa pelaksanaan strategi pembelajaran aktif tipe Active Knowledge Sharing pada materi integrasi dan reintegrasi dapat meningkatkan hasil belajar siswa pada aspek pengetahuan.

Gambaran mengenai peningkatan hasil belajar pada aspek sikap siswa pada setiap siklus dapat dilihat pada tabel 12 .

Tabel 12. Peningkatan hasil belajar pada aspek sikap tiap siklus

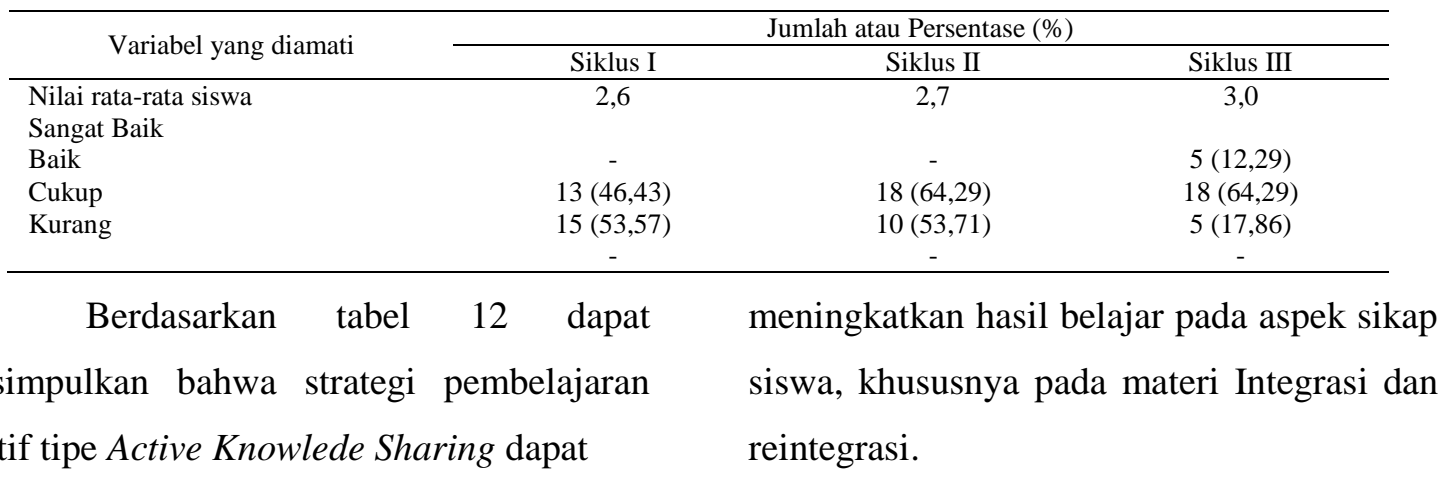

Tabel 13. Peningkatan hasil belajar pada aspek keterampilan tiap siklus

\begin{tabular}{lccc}
\hline \multirow{2}{*}{ Variabel yang diamati } & \multicolumn{3}{c}{ Jumlah atau Presentase (\%) } \\
\cline { 2 - 4 } & Siklus I & Siklus II & Siklus III \\
\hline Nilai rata-rata siswa & 2,56 & 2,67 & 2,79 \\
kategori A & - & - & - \\
kategori A- & - & - & - \\
kategori B+ & - & - & - \\
kategori B & - & - & $5(17,86 \%)$ \\
kategori B- & $9(32,14 \%)$ & $15(53,57 \%)$ & $18(64,29)$ \\
kategori C+ & $10(35,71 \%)$ & $8(28,57 \%)$ & $5(17,86 \%)$ \\
kategori C & $9(32,14 \%)$ & $5(17,86 \%)$ & - \\
& & & \\
\end{tabular}


Berdasarkan tabel 13 dapat disimpulkan bahwa strategi pembelajaran aktif tipe Active Knowledge Sharing dapat meningkatkan hasil belajar pada aspek ketreampilan siswa pada tiap siklus. Hal ini dikarenakan guru menerapkan strategi pembelajaran aktif tipe Active Knowledge Sharing berdasarkan hasil refleksi tiap siklus, sehingga rencana pelaksanaan pengajaran dapat terlaksanan dengan baik. Hasil yang diperoleh dengan menerapkan strategi pembelajaran aktif tipe Active Knowledge Sharing menunjukkan bahwa sikap, keterampilan dan pemahaman konsep Sosiologi siswa pada materi integrasi dan reintegrasi meningkat.

\section{KESIMPULAN}

Berdasarkan hasil penelitian
tindakan kelas yang telah dilaksanakan,
dapat disimpulkan strategi pembelajaran
aktif tipe Active Knowledge Sharing dapat
meningkatkan hasil belajar Sosiologi siswa
pada materi Integrasi dan Reintegrasi di
kelas XI IIS 1 SMAN 7 Sarolangun. Hal ini
dapat dilihat dari rata-rata persentase hasil
belajar pada aspek sikap pada siklus I adalah
46,43\% meningkat pada siklus II menjadi $64,29 \%$ dan meningkat lagi pada siklus III menjadi $76,58 \%$. Kemudian rata-rata persentase hasil belajar pada aspek keterampilan pada siklus I adalah 32,14\% meningkat pada siklus II menjadi 53,57 \% dan meningkat lagi pada siklus III menjadi $82,15 \%$. Sedangkan hasil belajar pada aspek pengetahuan, pada siklus I nilai rata-rata hasil belajar siswa adalah 62,95 dengan jumlah 28 siswa $(44,44 \%)$, meningkat pada siklus II menjadi 67,86 dengan jumlah siswa yang berhasil sebanyak 18 orang $(64,29 \%)$, kemudian meningkat lagi pada siklus III menjadi 75,00 dengan jumlah siswa yang berhasil sebanyak 22 orang $(78,57 \%)$.

\section{DAFTAR PUSTAKA}

Arkunto, Suharsimi (2015), Penelitian Tindakan Kelas, Jakarta: Bumi Aksara.

Koesoema, Doni, (2007) Pendidikan Karakter: Mendidik Anak di Zaman Global, Jakarta: Grasindo.

Sardiman, (2012), Interaksi dan Motivasi Belajar Mengajar, Jakarta: Grafindo Persada.

Sugiono, (2011), Metode Penelitian Kuantitatif, Kualitatif dan R\&D, Bandung: Alfabeta.

Yamin, Martinis (2003), Strategi Pembelajaran berbasis Kompetensi, Jakarta: Gaung Persada Press. 